\title{
UNITED STATES \\ ENVIRONMENTAL LAWS AND EXPLORATION AND PRODUCTION OPERATIONS
}

\author{
HENRY R. WHITE*
}

\begin{abstract}
Concern for the protection of the environment has resulted in the creation of a number of new U.S. statutes and regulations which have an important impact on American oil and gas exploration and production operations. The author provides a brief historical survey of some of the legislation which provided a foundation for laws enacted within the past few years. He discusses in some detail the National Environmental Policy Act provisions and concludes that they have been a constructive force for change, both in the government and the oil and gas industry. The author then provides an overview of various statutes and regulations establishing guidelines to ensure clean air and water, which are of particular importance to oil and gas producers. In conclusion, the author stresses the importance of maintaining a balance between the need for $a$ healthy environment and the need for an adequate supply of energy.
\end{abstract}

\section{INTRODUCTION}

The onslaught of environmental legislation in the United States in recent years has arisen out of a recognition that the land, water and air could no longer absorb man's waste. Before the natural systems would be irreparably damaged, human health severely impaired, and our aesthetic sensibilities dulled, an immediate national clean-up campaign was proposed to solve these impending problems.

Suddenly there were new agencies established, bringing about a mass transformation of governmental responsibilities; sophisticated scientific and technological studies were being conducted; life-saving programs were instituted; instant environmental experts were discovered. There were loud protests from environmentalists about industry being unresponsive to social concerns, and rebuttals by industry about anti-business evangelists and long-haired radicals attempting to abolish the free enterprise system. There were assaults on the government for its lack of foresight and inability to respond effectively to the crisis. Further, there was a new awareness in Middle America about the potentially adverse effect of major construction projects on all living organisms. This sensitivity reached such a peak that even the migratory pattern of the Alaskan caribou and musk-ox was of sufficient importance to alter and delay construction plans for the 4.5 billion dollar Trans-Alaska pipeline. Americans also became aware that alternatives now could and would be considered, whereas in the past there never seemed to have been a choice.

- Attorney, Atlantic Richfield Company, North American Producing Division, Dallas, Texas. Chairman, Mid-Continent Oil \& Gas Association Environmental Affairs Legal Subcommittee.

I would like to express my appreciation to Mr. Deming Cowles, Attorney, Atlantic Richfield Company, Anchorage, Alaska, for his assistance on this paper and to the Canadian Petroleum Law Foundation for the honor of participating in the 13th Annual Research Seminar. 
In spite of the immeasurable benefits which may have been derived from the environmental movement in recent years, the "Energy Crisis" has caused many people to reassess the importance of an undisturbed environment. The problems created by the simultaneous existence of the "Energy Crisis" and the environmental crisis have yet to be resolved. Whether the "Energy Crisis" might otherwise have overshadowed environmental concerns seems immaterial since recent legislation has forged a marriage of necessity between the two, which neither of the partners may dominate.

This paper is not designed to be a legal treatise, inundated with superfluous footnotes, esoteric theories or finely tooled distinctions of terms. It is a summary reference of environmental laws and regulations applying to U.S. oil and gas exploration, drilling and production operations.

\section{AN OVERVIEW OF THE EVOLUTION OF ENVIRONMENTAL LEGISLATION IN THE U.S.}

Contrary to popular opinion, the United States was involved in environmental control long before the 1970's. A historical survey reveals that Congress initially demonstrated its concern for the waters of the United States as early as 1899.

The Rivers and Harbors Act of $1899^{1}$ was enacted to prohibit the creation of any obstruction to the navigation of any waters of the United States which had not been authorized by Congress. Although the Act was designed to protect navigation, protection of the environment was a valuable by-product. The statute rendered unlawful the building of any wharf, breakwater, bulkhead, or other structures in any port, harbor, canal, navigable river or other waterway outside of established harbor lines, unless approved by the Corps of Engineers. The Act prohibited excavation or filling, altering or modifying the course, location, condition or capacity of any harbor, canal, lake, refuge, or the channel of any navigable waters of the United States, unless approved by the Corps of Engineers.

Another vintage statute which was originally designed to protect navigation, but was ultimately used for environmental protection, was the Refuse Act of 1899.2 This Act rendered it unlawful to throw, discharge, or deposit refuse matter of any kind or description whatever, other than that falling from streets and sewers, into navigable waters or any tributary thereof, of the United States.

The first Water Pollution Control Act was passed by Congress in $1948^{3}$ and it recognized the primary responsibilities and rights of the states in controlling water pollution. The Act's declared purpose was to support and aid technical research, to devise and perfect methods of treatment of industrial waste, and to provide federal technical assistance to states, interstate agencies, and industries. Further, it provided that pollution of interstate waters, which

1 Rivers and Harbors Act of 1889, 33 USC, § 401-413.

233 USC \& 407 (This section is referred to as the Refuse Act of 1899). Under this Act the Corp of Engineers had authority to issue discharge permits that would allow deposits of certain materials into navigable waters with defined limits. No permits for discharge were to be issued under this section after Oct. 18, 1971. The permit responsibility was transferred to the Environmental Protection Agency by Federal Water Pollution Control Act Amendments of 1972. Violation of 33 USC $\$ 407$, according to 33 USC $\$ 411$, constituted a misdemeanor and upon conviction a fine to be imposed not to exceed $\$ 2,500.00$ nor less than $\$ 500.00$ or imprisonment for not less than 30 days or both fine and imprisonment.

${ }^{8}$ Water Pollution Control Act, 62 Stat. 1155 (1948). 
endangered the health and welfare of persons in a state other than that in which the discharge originated, was a public nuisance subject to abatement. ${ }^{4}$

Congress strengthened and extended the $\operatorname{Act}^{5}$ by amendment in $1956^{\circ}$. The thrust of the amendment was directed toward comprehensive programs for water pollution control, cooperation between states, the establishment of uniform laws, and the establishment of a Water Pollution Control Advisory Board.

There were additional amendments in 1961 which, inter alia, extended the jurisdiction of the Federal Pollution Abatement Authority to all interstate or navigable waters. ${ }^{?}$

In 1965 Congress amended the federal Water Pollution Control Act by the Water Quality Act of $1965 .^{8}$ Administrative responsibilities were transferred from the Surgeon General to The Department of Health, Education and Welfare, and a federal Water Pollution Control Administration was established. The responsibility of the agency was to provide grants for research, to encourage the construction of municipal sewerage treatment works and to establish standards of water quality to aid in the prevention and abatement of pollution of interstate waters.

In 1966 the Clean Waters Restoration Act $^{\circ}$ was passed, which also amended the federal Water Pollution Act ${ }^{10}$ and strengthened the Oil Pollution Act of 1924. ${ }^{11}$ The Clean Waters Restoration Act authorized the Secretary of Interior to explore possible incentives to industry to abate water pollution, and provided a method whereby necessary environmental planning in respect of river basins could be achieved as a part of a broader approach to pollution control. The provisions of the Oil Pollution Act of 1924 were designed to protect the nation's coastal waters and adjoining shorelines against pollutants discharged from vessels. The 1966 amendment extended the application of the 1924 Act to navigable and interstate waters as well as to coastal waters and adjoining shorelines of the United States. ${ }^{11}$

The Water Quality Improvement Act of $1970^{12}$ amended certain other sections of the federal Water Pollution Control Act. Congressional reports supporting the preceeding acts relating to water pollution, dealt with what was happening to the water, what adverse effects pollution could have on our health, safety and development if it continued, and what had to be done to stop the continuing damage. It became evident that there were other areas to this broad problem which had not been covered, or had been inadequately covered, by existing laws.

1 Id.

Id.

6 Water Pollution Control Act Amendment of 1956, 70 Stat. 498 (1956).

7 Federal Water Pollution Control Act Amended, 75 Stat. 204 (1961).

8 Water Quality Act of 1965, 79 Stat. 903 (1965).

- Clean Water Restoration Act of 1966, 80 Stat. 1246 (1966).

10 Supra, n. 3.

11 The Oil Pollution Control Act of 1924 (Public Law 68-238); U.S. Code Cong. and Ad. News, 89th Cong. 2d Sess. (1966); see Legislative history, Sen. Rpt. No. 1367, at 3969-3986; Conference Rpt. No. 2289, at 3986-3998, see specifically 3981 . Oil discharges were prohibited not only from vessels but from boats, shore installations, and terminal facilities. The shore installations which were intended to be within the scope of this Act were those facilities at which oil is a primary production factor and which either receive oil or oil products from, or discharge oil or oil products to, boats, vessels, and terminal facilities.

12 Water Quality Improvement Act of 1970, 84 Stat. 91. 
The inadequacies of the existing laws were further illuminated by major oil spills which had occurred. For example, the Oil Pollution Act of 1924 applied only to discharges and spills that were grossly negligent or wilful. Its applicaonly to discharges and spills that were grossly negligence or wilful. Its application was essentially limited to vessels - it did not apply to spills from fixed installations such as pipelines, oil deposits, refineries or manufacturing plants, or other spills resulting from types of industrial activity using and storing large quantities of oil. ${ }^{13}$ Thus, the Water Quality Improvement Act of 1970 which repealed the Oil Pollution Act of 1924, filled many of the gaping holes in the pollution control program. ${ }^{14}$

The purported panacea to the nation's water problems was enacted more recently as the federal Water Pollution Control Act Amendments of 1972. ${ }^{15}$ This Act will be discussed briefly later in this paper as it pertains to the oil industry.

With respect to air pollution, Congress indicated that in the years prior to 1955 the health and welfare of people in many parts of the country were being adversely affected by contamination of the atmosphere. ${ }^{16}$ This contamination resulted from the emission of fumes and particulate matter into the air above heavily populated communities and industrial centers and caused what was commonly described as "smog and smaze". Because of public alarm, legislation followed in the form of the Air Pollution Control Research and Technical Assistance Act. ${ }^{17}$ This 1955 Act established the basic air quality research and technical assistance program. ${ }^{18}$

In 1959 the program was extended and Congress declared its desire that federal agencies cooperate with the Department of Health, Education and Welfare and with state, local and interstate air pollution control agencies regarding discharges from federal facilities. ${ }^{10}$ With the increase in the number of automobiles and the resultant air pollution problems created by their exhaust emissions, Congress took steps in 1960 to study ways of controlling motor vehicle discharges. ${ }^{20}$

The result was legislation such as the Clean Air Act, enacted in 1963, 21 the Motor Vehicle Air Pollution Control Act,"22 enacted in 1965, and the Clean Air Amendment of $1966,,^{23}$ all of which provided the foundation for the Air Quality Act of $1967 .^{24}$ This legislation generally provided for the development of federal air quality guidelines, guidance and assistance to local agencies for

13 U. S. Code Congressional \& Admin. News, 91st Cong. 2nd Secc. 1970, House Rept. No. 91-127, at 2692.

14 Water Quality Improvement Act of 1970, Sec. 108 provides: The Oil Pollution Act, 1924 (43 Stat. 604), as amended ( 80 Stat. 1246-1252 or 33 USCA, Sec. 431-437) is hereby repealed.

1533 USC, 1251 et seq., PL 92-500; enacted by Congress, October 18, 1972, overriding the President's veto of October 17, 1972, as amended by PL 93-217, December 28, 1973, and PL 93-243, January 2, 1974.

${ }^{16}$ U. S. Code Cong. and Admin. News, 84th Cong., 1st Sess. 84th Cong., 1st Sess. (1955), Sen. Rep. No. 389, at 2457.

17 Air Pollution Control Research and Technical Assistance Act, 69 Stat. 322 (1955).

18 Id.

10 Act of September 22, 1959, 73 Stat. 646.

20 Act of June 8, 1960, 74 Stat. 162.

21 Clean Air Act, 77 Stat. 392 (1963).

22 Motor Vehicle Air Pollution Control Act, 79 Stat. 992 (1965).

23 Clean Air Amendments of 1966, 80 Stat. 954 (1966).

24 Air Quality Act of 1967, 81 Stat. 485 (1967). 
abatement proceedings, and the establishment of national emission standards for new motor vehicles.

The Air Quality Act of $1967^{25}$ followed the cooperative federalism approach of the then existing water statutes. The Act included provisions allowing the federal government to issue air quality guidelines. The states could then establish abatement plans to achieve the level of air quality set out by the federal government. The Act provided the states with additional guidance on ways to carry out their air pollution responsibilities. If they took no action, or took inadequate action, the federal government would establish federal standards to be enforced by the states. Also included was a provision creating injunctive powers, and a $\$ 1,000$ fine designed to provide some enforcement power to insure positive results. Certainly Congress must have thought that it had a tool with which to solve the growing air pollution problems. However, once the Air Quality Act of 1967 was put into effect, it was soon realized that the Congressional Game Plan was not going to be a winner. Progress under the Act was regretably slow due to cumbersome and time-consuming procedures, inadequate federal, state, and local funding, the scarcity of skilled personnel to enforce control measures, the inadequacy of available test and control technology, and organizational problems on the federal level where air pollution control had not been accorded a sufficiently high priority. ${ }^{28}$

\section{THE ROARING 70's}

The present decade is seeing a veritable explosion of environmental laws and regulations at all government levels. No single reason exists which solely explains the explosion, nor will the brevity of this paper permit mentioning more than a few causes. Depletion of a natural resource is of particular environmental concern to a highly technological society which depends upon resources for energy, building materials and recreation. On occasion, resource exploitation methods seem to have created problems greater than the value of the resources themselves.

A classic example showing why the federal government was concerned with increasing controls over the oil industry was the Santa Barbara Oil Spill. On January 28, 1969, an oil well off the California Coast in the Santa Barbara Channel, operating pursuant to the Outer Continental Shelf Act $^{27}$ under a perimit issued by the Corps of Engineers and mineral leases granted by the Bureau of Land Management of the Department of the Interior, "blew out", eventually leaking approximately 2,000,000 gallons of oil to the surface of the Santa Barbara Channel. It took ten and one-half days to plug the well. Eventually the oil which had leaked from the "blow out" affected beaches as far south as Mexico. In addition to the oil making the Santa Barbara beaches unusable well past Labor Day in 1969, the oil also did extensive short term damage to fish and bird life. The effect on the Santa Barbara economy, where the tourist trade depends heavily on the use of the channel and beaches for swimming, boating, fishing, bird watching, skin diving, and upon the aesthetics of life for nearby residents, was equally severe.

Accidents during routine work, maintenance and repair have resulted in at least two large oil spills, along with destruction of platforms, the loss of a work vessel and of several human lives. On May 28, 1970, renovation and repair

25 Id.

28 U.S. Code Cong. \& Admin. News 90th Cong. 1st Sess. (1967). Legislative history, H. Rpt. No. 728. 
work were being carried out on a platform in Galveston Block 189-L, off the Texas coast. The platform had been shut-down and workmen were sandblasting, painting, torch-cutting and welding. When welding was attempted on a line leading to a storage tank containing 2,000 barrels of crude oil, a series of explosions occurred resulting in the death of five workmen and injuries to six. Burning oil spilled onto a nearby service boat, nearly destroying it, and about 100 barrels also reached shore, polluting Galveston beaches (National Transportation Safety Board, 1970)..$^{28}$

The Bay Marchand Fire occurred in 1970-71, when the plastic coating on the tubing of one well sloughed off and plugged the tube during cleaning operations. Workmen had failed to close the well control valves for a brief period while the well was left unattended. The well blew off and the fire ignited. Ten of the other 21 wells on the platform were damaged by the initial explosion and also blew out and caught fire. Four workmen died immediately. After five months, the last of the blowing wells was capped (Nelson, 1972). An undetermined amount of petroleum was consumed by the fire and 53,000 barrels spilled into the sea. Such an accident on a gas producing platform might still result in loss of life and equipment, but most likely would not cause a significant impact on the environment. ${ }^{29}$

As a result of these and other incidents, the Department of the Interior tightened its regulations governing offshore oil drilling. ${ }^{30}$ The new regulations called for: (1) full consideration of all environmental factors including aquatic resources, aesthetics and other resources, before a decision on leasing is made; (2) more stringent technical requirements for drilling wells, casing the hole and cementing it to prevent spills; (3) prior review and acceptance by an official of the Department of the Interior, present at the drill site, of plans and equipment to prevent pollution, blowouts and leakage; (4) frequent testing of blowout prevention devices; (5) suspension of operations, including production, which in the judgment of the government threaten human life, marine life, property, mineral deposits, or other environmental concerns. ${ }^{31}$

Not too long ago an attorney who had an oil and gas exploration, drilling, or producing client had only to primarily concern himself with the well-established oil and gas principles that apply to land owners' interests, oil and gas leases, and conservation problems. Even now, with little provocation, many attorneys, as well as their clients, will bellow, "I remember when we didn't have to fool with all of this environmental crap", or "What are they trying to do - run us out of business?” The 1970's are bringing about a whole new way of doing business in the oil industry.

\section{ENVIRONMENTAL LAWS AND THE CLIENT}

How do you advise a client who asks the question "What are the environmental laws and how do they affect my exploration, drilling or production operations"? Although this question seems sufficiently basic and is one that an

2743 USC, § 1331, et seq.

28 United States Department of the Interior. Final Environmental Statement, proposed 1972 Outer Continental Shelf Oil and Gas General Lease Sale Offshort Eastern Louisiana (June 20, 1972) 58-73.

29 Id.

${ }^{30}$ See Hearings Committee on public works: Subcommittee on Air and Water Pollution, 91st Cong., lst Sess., Feb. 5-6, 24, 25, 1969, pertaining to Santa Barbara Case.

8130 CFR, Part 250; 43 CFR, Part 3380; 34 Fed. Reg. 13544-13550 (Aug. 22, 1969 ). 
oil and gas client needs to have answered, there are no hard and fast guidelines or legal procedure manuals yet published which will give a packaged answer, due perhaps to the many variables associated with the industry, and the changing environmental laws.

Perhaps the best way to begin this discussion is to identify the activities related to the oil and gas industry which are affected by environmental laws and regulations. These activities include seismic operations, exploratory drilling, development drilling, operation of pipelines to either onshore or offshore production facilities, and the operation of the onshore and offshore production facilities themselves. Again you are reminded that this paper was not intended to cover all functions of the industry, such as transportation, marketing, refining or pipeline operations.

Where does a client's first confrontation with an environmental regulation take place? It should begin when he first decides that seismic operations are necessary. For example, the Bureau of Land Management, an agency in the Department of Interior, requires in their regulations the filing of a "Notice of Intent to Conduct Oil and Gas Exploration Operations". ${ }^{32}$ This "notice of intent" requirement only pertains to exploration operations to be conducted on public land. It does not apply to the exploration operations conducted pursuant to an oil and gas lease, nor does it apply to exploration of public domain lands subject to location under United States mining laws. A notice of intent does not have to be filed if there is only a "casual use" 33 of the lands in which the exploration activity is being conducted. That means that the activity will not lead to any appreciable disturbance of, or damage to, lands, resources, and improvements. This would, of course, rule out the use of heavy equipment or explosives or the driving of vehicles over other than established roads and trails.

Once the exploration operation is completed, the client would be required to file a "Notice of Completion of Oil and Gas Exploration Operations".34 This notice would be reviewed by the District Manager of the Bureau of Land Management and the Area Inspector to determine if any additional measures must be taken to rectify any damage to the land.

In some instances where a seismic operation is conducted on state-owned land, it is necessary to obtain permission from the appropriate state agency. For example, in Alaska where approximately 95 percent of the land in the state is owned by either the federal government or the state government, permission must be obtained from the state Department of Natural Resources and from the Bureau of Land Management, its federal counterpart. Approval is normally conditional upon stipulations that guard against environmental damage. Generally, the operations must be conducted in a manner that will not disturb the spawning fish, wildlife, trees and ground cover, etc. Conditions requiring restoration of the land prior to completion of the seismic operations are also included.

If seismic operations are conducted in the water, approval must be obtained from either the state or from the United States Geological Survey. In Alaska a "Miscellaneous Land Use Permit" from the state is circulated through the Department of Environmental Conservation and Fish and Game. The U.S.G.S. application is circulated through the Bureau of Sport Fisheries and Wildlife. The environmental concern about seismic operations, as well as about resultant 
exploratory drilling and production, is best exemplified by the long-term controversy over the Kachemak Bay of Cook Inlet in Alaska. For quite some time, seismic boat operations have been charged with interferring with the crab and fish industries in the area. Expensive nets and pots have been separated from their moorings when vessels, including seismic boats, pass through fish-laden seas. In addition, there is a constant fear that if exploratory drilling is permitted in those areas, oil spills will occur which will pollute the fish and crab areas. Public hearings have been held by state legislators; residents of the communities around Kachemak Bay have been vocal in their complaints, which include strong threats of litigation, to the state Division of Lands and the state Department of Natural Resources. It has been suggested that transportation corridors be established so that both fishing and oil-related activities can be conducted harmoniously. This example points out that the environmental protection proponents are not necessarily cause-oriented, idealistic factions, but also include industries with major economic interests.

\section{NEPA AND FEDERAL LEASE SALES}

In terms of real estate transactions the Bureau of Land Management of the Department of Interior is likely the largest landlord in the United States. Pursuant to the Outer Continental Shelf Lands Act, ${ }^{35}$ the Director of the Bureau of Land Management is authorized to issue on a competitive basis, leases for oil and gas, sulfur and other minerals in submerged lands on the Outer Continental Shelf.

When an area is under consideration for a lease sale by the Director of the Bureau of Land Management, summary reports describing the general geology and potential mineral resources of the area are requested from the Director of Geological Survey and from other federal agencies which might have information on valuable resources within the considered area or any information on the potential effect of mineral operations upon the resources or the total environment. ${ }^{36}$

Before making the final selection of the tracts for leasing, the Director is required by regulation to evaluate fully the potential effect of the leasing program on the total environment, aquatic resources, archeological resources, aesthetics, recreation, and other resources in the entire area during exploration, development and operational phases. ${ }^{37}$ The Director is further required to consult with appropriate federal agencies as to their views. However, the Director has discretion to determine whether a public hearing, or consultation with state agencies, organizations, industries and individuals, is necessary. ${ }^{38}$

As an additional environmental control, the Director is required to develop special leasing stipulations and conditions when necessary to protect the environment and all other resources. These conditions are to be included in the proposed notice of lease offer. ${ }^{39}$

In addition to the Bureau of Land Management regulations governing a lease sale, there is an omnipotent statutory force that pervades all governmental agencies, which requires an extensive analysis of the impact of an agency's decision on the environment.

\footnotetext{
s5 43 USC, § 1331, et seq.

3643 CFR 3300.4.

3743 CFR 3301.2.

3843 CFR 3301.4.

8043 CFR 3301.4.
} 
This power is manifested in Section 102(2)(C) of the National Environmental Policy Act of 1969 (NEPA). ${ }^{40}$ Perhaps the most important aspect of the National Environmental Policy Act"11 is that it provides ... "all agencies and all federal officials with a legislative mandate and a responsibility to consider the consequences of their actions on the environment."12

In the New York Times on May 3, 1969, it was stated: ${ }^{43}$

By land, sea and air, the enemies of man's survival relentlessly pressed their attack. The most dangerous of all these enemies is man's own undirected technology. The radioactive poisons from nuclear tests, the runoff into rivers and nitrogen fertilizers, the smog from automobiles, the pesticides in the food chains, and destruction of top soil by strip mining are examples of the failure to foresee and control the untoward consequences of modern technology.

NEPA was designed to remedy many of these national environmental ills through a review and analysis procedure conducted by agencies prior to approving a project. Probably for the first time the government had a "show and tell" program.

The purposes of the Act are: "To declare a national policy which will encourage productive and enjoyable harmony between man and his environment; to promote efforts which will prevent or eliminate damage to the environment and biosphere and stimulate the health and welfare of man; to enrich the understanding of the ecological systems and natural resources important to the Nation; and to establish a Counsel on Environmental Quality."'4t

To comply with the legislative mandate that all agencies consider the consequences of their actions on the environment, federal agencies are to do the following:

Section 102(2)(C). Include in every recommendation or report on proposals for legislation and other major federal actions significantly affecting the quality of the human environment, a detailed statement by the responsible official on -

(i) The environmental impact of the proposed action,

(ii) Any adverse environmental effects which cannot be avoided should the proposal be implemented,

(iii) Alternatives to the proposed action,

(iv) The relationship between local short-term uses of man's environment and the maintenance and enhancement of long-term productivity, and

(v) Any irreversible and irretrievable commitments of resources which would be involved in the proposed action should it be implemented.

The responsible federal official is further required to consult with and obtain the comments of any federal agency which has jurisdiction by law or special expertise with respect to any environmental impact involved.45 The Council on Environmental Quality has established guidelines for the federal agencies to aid in the identification of major actions significantly affecting the

10 The National Environmental Policy Act. For a Summary of the Law see Yannacone \& Cohen, Environmental Rights and Remedies 150-214 (1972).

41 Id.

12 SR No. 296, \& Conf. Rpt. No. 765, 91st Cong. lst Sess. 14 (1969).

13 U. S. Code Cong. \& Admin. News, 9lst Congress, 1st Session (1969). See Legislative History 2753.

442 USC, 4321 et seq. (1970). For analysis of NEPA, see Friedman, The National Environmental Policy Act of 1969 - The Brave New World of Environmental Legislation, (1973) 7, Natural Resources Lawyer 44.

45 USC 4332. 
environment ${ }^{46}$ and to guide them in the preparation of the environmental impact statements.

What does this mean to one concerned with oil and gas production in the Outer Continnental Shelf? It simply means that more lead time must be allowed in planning future exploration and production operations. ${ }^{47}$ There is no assurance as to how quickly acreage may be acquired to drill a lease after a successful bid, in spite of large sums expended on exploration activities.

In June, 1972, a lease sale took place off the Eastern Louisiana coast, where some 78 tracts, or 366,440 acres, of OCS land were proposed for leasing consideration. ${ }^{18}$ The summary of the final report read:

All tracts offered posed some degree of pollution risk to the marine environment and/or adjacent shoreline. The risk potential is related to adverse effects on the environment and other resource use which may result from accidental or chronic oil spillage. Since the location of an OCS tract in relation to resources is an important consideration in assessing environmental risk potential, all tracts have been ranked according to their distance from shore or from high value/critically vulnerable resources. ${ }^{40}$

In compliance with NEPA, the statement delineates alternatives to the lease sale, some of which are: ${ }^{50}$

1. Hold the sale in modified form. A modification of the sale would consist of offering only those tracts determined to have a low potential for environmental risk. Those tracts which were believed to have high environmental risk, would be deleted from the sale and considered at a later date, should improved technology or other circumstances warrant. Another possible modification proposed was to offer only those tracts estimated to be gas producing. This would reduce the potential hazard of oil pollution.

2. A second alternative considered in the impact statement was to "delay the sale" until new technology is available to provide increased environmental protection.

3. Another alternative to modification of the proposed sale would be to "withdraw". As an alternative it appears the least attractive inasmuch as it impedes meeting future energy demands and would necessitate development of alternative sources of energy. Some alternative sources to offshore oil and gas development are: increased oil imports, increased onshore oil and gas production, increased nuclear power, increased use of coal, increased hydroelectric power and modification of FPC natural gas pricing. ${ }^{51}$

Within the past three years, the federal courts have considered over three hundred NEPA cases, interpreting and extending the language of the Act. Most

4838 Fed. Reg. 20550 (Aug. 1, 1973) - Council on Environmental Quality. Preparation of Environmental Impact Statement Guidelines.

17 Friedman, Counseling the Corporate Client in Preparing Environmental Impact Statements: The Lawyer's Role at 47-54 (PLI) (1973).

48 U. S. Department of the Interior, Final Environmental Statement, Proposed 1972 Outer Continental Shelf Oil and Gas General Lease Sale Offshore Louisiana. (June 20, 1972).

19 Id.

50 Id.

51 Id. 
of the litigation to date has focused on some aspect of section 102 of the Act. These cases have developed a reasonably conclusive reservoir of case law which can now be relied on in preparing environmental impact statements. Some of the more important issues raised, since the inception of the statute, have been those pertaining to when an impact statement must be prepared; ${ }^{52}$ whether a federal agency could delegate its responsibility for preparation of an EIS to a state or state agency; ${ }^{53}$ what constitutes major actions and significant effects; ${ }^{54}$ when the final statement adequately satisfies the statutory requirement "to the fullest extent possible"; 55 when the statement is sufficiently "detailed" to satisfy the "full disclosure" requirement about the project; and to what extent alternatives must be considered. ${ }^{50}$ These questions and many others have been resolved by case law, which to a great extent has provided some clarity and order to something which originally appeared to be destined for bureaucratic pandemonium and industrial neurosis.

In spite of the reluctant acceptance of NEPA, it would appear fair to say that NEPA has been a force for constructive change, in oil companies as well as in the federal government, by creating a greater sensitivity to environmental considerations and forcing a decision making process that embraces a broader spectrum of values.

\section{OPERATING WITH CLEAN WATER}

Having found that many of the nation's navigable waters were severely polluted, that major waterways near industrial and urban areas were unfit for most purposes, that rivers were the primary carriers of pollution to coastal waters, that the oceans and many lakes confined to waterways were aging rapidly under the impact of increased pollution, that rivers, lakes and streams were being used to dispose of man's waste rather than to support man's life and health, and that the use of any river, lake, stream, or ocean as a waste treatment system was unacceptable, Congress established the following national policies: ${ }^{57}$

1. That the discharge of pollutants into the navigable waters be eliminated by 1985 ;

52 Daly v. Volpe 4 ERC 1481, 1485. The Court said:

The environmental impact statement was intended by Congress to provide decision-making bodies with sufficient information to make an environmentally sound decision, not to offer evidence of the wisdom of that decision once it has been made.

${ }^{53}$ The law is unsettled as to whether a federal agency's responsibility to prepare an impact statement can be delegated. Green County Planning Board v. Federal Power Commission 3 ERC 1595 (did not permit delegation of responsibility). National Forest Preservation Group v. Volpe 4 ERC 1836 (permitted delegation with restrictions).

54 Natural Resources Defense Council v. Grant 3 ERC 1883, 4 ERC 1657, 1659, 5 ERC 1001. Handley v. Kleindienst 4 ERC 1785, 1789 suggests the following factors be considered:

To the extent to which the action will cause adverse environmental effects in excess of those created by existing uses in the area affected by it and the absolute quantitative adverse effects of the action itself, including the cumulative harm that results from its contribution to existing adverse conditions or uses in the affected area.

${ }^{55}$ Calvert Cliffs v. A.A.E.C. 2 ERC 1779, 404 U. S. 942 (1972) unequivocally suggests that strict compliance is required.

56 EDS v. Corps of Engineers 2 ERC 1260, 4 ERC 1097, 1721, 5 ERC 1416. The Court said: "At the very least, EPA is an environmental full disclosure law."

5786 Stat. 816, (1972) 33 USCA 1251 et seq. 
2. That whenever obtainable, an interim goal of water quality which provides for the protection of fish, shellfish, and wildlife and provides for recreation in and on the water be achieved by July 1, 1983;

3. That the discharge of toxic pollutants and toxic amounts be prohibited;

4. That federal financial assistance be provided to publicly-owned waste treatment works;

5. That the area-wide waste treatment management planning process be developed and implemented to assure adequate control of sources of pollutants in each state; and

6. That a major research demonstration effort be made to develop technology necessary to eliminate the discharge of pollutants into navigable waters, waters of the contiguous zones, and the oceans.

The federal Water Pollution Control Amendment Act of 1972,58 takes a new approach to control discharges into the nation's waterways. Rather than relying totally on the previous approach of setting water quality standards, the primary requirement of the 1972 Act is the establishment of effluent limitations for each point discharge source. Precise maximum numerical limitations on waste loads from a point source are to be established. In order to discharge from that point source a permit is now required. Effluent limitations are to be achieved by requiring state-of-the-art controlled technology. By July 1, 1977, production operations must meet effluent limitations reflecting application of the best practicable controlled technology currently available..$^{50}$ Effluent limitations will be enforced by EPA under the National Pollutant Discharge Elimination System ${ }^{10}$ which contains detailed provisions for approval of state programs to authorize states to assume administrative responsibility. The permits place specific pounds-per-day limitations on effluents from each discharge point source. These permits are not to exceed five years and may be terminated for a violation of a permit condition, misrepresentation, or a change in condition. All permits that were once issued under the Refuse Act of 1899, now come under the National Pollutant Discharge Elimination System.

It should be noted that the basis of the law is to prevent the discharge of "pollutants" into "navigable waters, contiguous zones and the oceans." Of particular importance to the producers is section 502(6) of the Act which provides that "pollutant" does not mean ... ${ }^{61}$

(D) water, gas or other material which is injected into a well to facilitate production of oil or gas, or water derived in association with oil or gas production and disposed of in a well, if the well used either to facilitate production or for disposal purposes is approved by authority of the state in which the well is located, and if such state determines that such injection or disposal will not result in the degradation of ground or surface water resources.

The law essentially retains state authority for control of subsurface injection wells and production operations. EPA has authority to protect all waters and jurisdiction over injection wells not for production operations. "Navigable

\footnotetext{
58 Id.

59 Id., § 301 (b) (I) (A) or 33 USCA 1311 (b) 1 (A).

60 Id., \$ 402 or 33 USCA 1342.

61 Id., $\S 502(6)$ or 33 USCA 1362(6).
} 
waters $^{p_{62}}$ has been defined as waters of the United States, including the territorial seas. This is a more expansive definition of navigable waters than some previous interpretations and eliminates the question of applicability of the law to tributaries.

The Act requires in section 306(B) that the administrator publish a revised list of industry categories subject to "national standards of performance" and regulations establishing federal standards of performance for new sources within each category. "The term 'standard of performance' means a standard for control of the discharge of pollutants which reflects the greatest degree of effluent reduction ... . achievable through application of the best available demonstrated control technology, processes, operating methods ..." as determined by the administrator. ${ }^{63}$ The initial list of 27 categories includes "petroleum refining" but not drilling, production or gas processing.

The Act declares that the discharge of oil or hazardous substances into or upon the navigable waters of the United States or adjoining shorelines, or into the contiguous zones in harmful quantities is prohibited. ${ }^{\text {it }}$ This section of the Act further provides that any person who has knowledge of a discharge in violation of the Act shall immediately notify the appropriate agency of the United States of such discharge. ${ }^{.5}$ Any person who fails to do so shall upon conviction be fined not more than $\$ 10,000.00$, or be imprisoned for not more than one year, or both. ${ }^{\circ 6}$ The Coast Guard has been designated as the appropriate agency to -ceive notices of discharge of oil as required by section 11(B) (4) of the Water Quality Improvement Act of 1970. ${ }^{6 \tau}$ In the Gulf of Mexico region, by agreement between the Coast Guard and EPA, a report of discharge may be made to the EPA in the area where EPA is designated as responsible for on-scene coordination of oil spill cleanups. A civil penalty may be assessed in the amount of not more than $\$ 5,000.00$ for each offense for a discharge of oil or a substance from any vessel, onshore facility, offshore facility in harmful quantities. ${ }^{88}$ No penalty shall be assessed unless the owner or operator charged shall have been given notice and an opportunity for a hearing on the charge.

Aside from the National Pollutant Discharge Elimination System, the other most demanding regulation that has evolved from the 1972 Water Amendments is the Oil Pollution Prevention Regulation ${ }^{60}$ for non-transportation related onshore and offshore facilities. The regulation was designed to establish procedures, and requirements for equipment, to prevent discharge of oil into

62 Id., $\S 502(7)$ or 53 USCA 1362(7). As defined by the Act:

(7) The term 'navigable waters' means the waters of the United States, including the territorial seas.

(8) The term 'territorial seas' means the belt of the seas measured from the line of ordinary low water along that portion of the coast which is in direct contact with the open sea and the line marking the seaward limit of inland waters, and extending seaward a distance of three miles.

(9) The term 'contiguous zone' means the entire zone established or to be established by the United States under article 24 of the Convention of the Territorial Sea and the Contiguous Zone.

(10) The term 'ocean' means any portion of the high seas beyond the contiguous zone.

${ }^{68}$ Id., \& 306 (a) (1) 33 USCA 1316 (a)(1).

64 Id., § 311(b)(2)(A) 33 USCA 1321(b)(2)(A).

${ }^{65} I d$., § 311 (b) (5) 33 USCA 1321(b)(5).

${ }^{60} I d$.

6784 Stat. 91.

6886 Stat. $311(b)(6)$.

6940 CFR 112. 
and upon navigable waters of the United States or adjoining shorelines. It applies specifically to owners and operators of non-transportation-related onshore and offshore facilities engaged in drilling, producing, gathering, storing, processing, refining, transferring, distributing or consuming oil and oil products which because of their location, could reasonably be expected to discharge oil in harmful quantities into and upon navigable waters of the United States or adjoining shorelines. These owners and operators are required to prepare a Spill Prevention Control and Countermeasure Plan by July 10, 1974, to detail what equipment will be used and what steps will be taken to prevent oil spills. A separate SPCC Plan must be prepared for each facility. For example, a geographical oil field is a "facility". These regulations do not apply to:

(1) facilities which have an aggregate storage of 1,320 gallons or less of oil, provided no single container has a capacity in excess of 660 gallons; (2) facilities which have a total storage capacity of 42,000 gallons or less of oil and such total storage capacity is buried underground; and (3) non-transportation-related onshore and offshore facilities, which due to their location could not reasonably be expected to discharge oil into or upon the navigable waters of the United States or adjoining shorelines. In addition, the Coast Guard has promulgated regulations for transportation-related facilities. ${ }^{70}$ These regulations are concerned with the transfer of fuel between vessels and onshore or offshore facilities.

\section{CLEAN AIR AND PRODUCTION OPERATIONS}

The air counterpart to the federal Water Pollution Control Act of 1972, is the Clean Air Amendments of $1970 . .^{71}$ The following is an overview of those provisions of primary interest to the oil and gas producer.

Congress in 1970, responding to a variety of pressures, recognized: ${ }^{72}$

... that the growth and the amount and complexity of air pollution brought about by organization, industrial development, and the increasing use of motor vehicles, has resulted in mounting dangers to the public health and welfare, including injury to agricultural crops and livestock, damage to and the deterioration of property, and hazards to air and ground transportation; . that the prevention and control of air pollution at its source is the primary responsibility of states and local governments. . . .

With this new-found awareness Congress set forth the following purposes of the Clean Air Act Amendments of 1970: ${ }^{73}$

1. To protect and enhance the quality of the Nation's air resources so as to promote the public's health and welfare and the productive capacity of its population;

2. To initiate and accelerate a National Research and Development Program to achieve the prevention and control of air pollution;

3. To provide technical and financial assistance to state and local governments in connection with the development and execution of their Air Pollution Prevention and Control Programs; and

4. To encourage and assist in the development and operation of Regional Air Pollution Control Programs.

7033 CFR 153-156.

7142 USC $\$ 1857$ et seq. (1971).

72 U. S. Code Cong. \& Admin. New. 91st Cong. 2nd Sess., H.R. No. 1146.

${ }^{73}$ Supra, n. 71. 
Under the Act each state has primary responsibility for assuring air quality within the entire state by submitting an implementation plan which will specify how national primary and secondary air quality standards will be achieved within each air quality control region of the state. The state or interstate geographic air control regions are established by EPA as needed. EPA has published a list of air pollutants which (a) have an adverse effect on public health or welfare, and (b) which are emitted from numerous mobile or stationary sources. Air quality criteria for the list of pollutants are to be published for all identifiable effects on public health or welfare by the Environmental Protection Agency. Ambient air standards for each pollutant for which air quality criteria have been issued have also been published. ${ }^{74}$

The states are to prepare and submit to EPA for approval plans for implementation, maintenance and enforcement of the national primary and secondary air quality standards. According to the Act, if the state fails to submit a plan to EPA, or if the plan submitted is considered inadequate, EPA may prepare and publish a plan for the state: 75

Categories of new stationary sources which may emit air pollutants and then standards of performance for new sources in each category are to be published by EPA. Further, a list of hazardous air pollutants with emission standards for such pollutants have been published.

Failure or refusal to comply with a requirement of any implementation plan can subject the violator to a fine of $\$ 25,000$ per day of violation and one year imprisonment, and for additional convictions, $\$ 50,000$ per day and two years imprisonment. ${ }^{76}$ A self-surveillance method is provided by the Act to the extent that the operator may be required to monitor emissions and keep records. ${ }^{77}$ Of course, EPA has the right of entry onto the premises to inspect or evaluate the monitoring methods used.

Of the many regulations which have been promulgated by the EPA under the Clean Air Act, the most important to the producer in terms of relief would be the regulations on Standard of Performance for New Stationary Sources published on March 8, 1974. ${ }^{78}$ Of primary concern to the producing industry was the section of the regulations dealing with standards of performance for storage vessels for petroleum liquids. The initial draft regulation would have required the installation of vapor recovery systems on all storage vessels in a producing field. Fortunately, the final version exempted storage vessels for crude condensate stored, processed and/or treated at a drilling and production facility prior to custody transfer.

Thus far, the Clean Air Act and its regulations have not had a significantly restrictive impact on drilling and producing operations. Because of the area in which drilling operations are generally conducted, contamination normally does not have a significant deleterious effect. There are cases, of course, where natural gas instead of mud has been used as the controlling and circulating medium during drilling operations. The gas from this process is usually flared because of the impracticality of reuse. The small amount of gas resulting from oil testing is usually flared. The determining factor of whether the flaring of these gases is prohibited would depend upon applicable provisions of state implementation

7439 FR 25678 (Sept. 14, 1973).

7540 CFR 61, 38 FR 8920 (April 6, 1973).

7642 USCA 1857C-8 or $\$ 113(\mathrm{c})(1)$ (c) of the Act.

7742 USCA $1857 \mathrm{C}-9$ or $\$ 114$ (a)(1) of the Act.

7839 FR 9308 (March 8, 1974). 
plans. State implementation plans generally have strictly regulated sulphur dioxide emissions from sulphur recovery plants. Offshore operators and shore based facilities can likewise expect the scrutiny of the state because of restrictions on hydrocarbon storage, sulphur dioxide emission, and trash incinerators.

In many instances the environmental law in an area has not evolved in an orderly manner. Legislatures, under heavy public pressures to enact strong measures to protect the environment, have often acted precipitously without insuring that the total fabric of laws and regulations between the federal, state and local governments are coordinated, capable of successful implementation, consistent and non-duplicative. There has been much confusion over the interpretation of terms in some of the legislation. Additional problems have been created by the large number of governmental agencies that are involved in the implementation of the legislation.

Because of the newness of this vast area of environmental control, the lack of adequate technical data on the precise harmful effects of various pollutants has further complicated enforcement measures. Perhaps this is the result of an adoption of regulations based on superficial criteria which failed to adequately appraise and reflect the true extent of the injury to environment, the technological capability of industry to curtail its discharge of pollutants without causing severe disruptions in employment and energy supplies, the time period reasonably required to install anti-pollutant devices, and the ultimate cost to the consumer.

A senior official of the Environmental Protection Agency admitted that EPA pollution control regulations were "so complex they could only be understood by the author."79

\section{CONCLUSION}

This paper is not intended to suggest that the laws discussed are the only environmental laws to be considered in respect of exploration, production or drilling operations. Just as important as the primary federal environmental laws canvassed are the state environmental laws and regulations. States are increasingly enacting laws requiring reporting of oil discharges with penalties for failure to do so. Some states also have little NEPA's, water quality and effluent standards, air quality standards and sanctions which, in all cases, are equal to or more stringent than those provided in the federal laws and regulations.

Perhaps of paramount concern to the oil and gas operator and his lawyer at this point would be an environmental prognosis, in the light of the need for increased exploitation of oil and gas resources. An Environmental Protection Agency administrator stated ${ }^{\mathrm{s}}$ that the majority of the Environmental Protection Agency work does not impinge significantly on the energy crisis and is not being slowed down by it. He stated further that:

${ }^{70}$ Article published in the Houston Chronicle on April 30, 1974. The Administrator was the Director of the Environmental Protection Agency, Office of Legislation. He further stated according to the article:

No criticism of EPA would be complete without a few words about our regulations, which in the past have been mind-boggling in complexity.

In the face of a clear instruction from the Congress in the Clean Water Amendments of 1972 to do away with red tape and follow formalisms, we came out with some regulations so complex that they could only be undestood by the authors.

${ }^{80}$ U. S. Environmental Protection Agency, Environmental News, released Dec. 13, 1973. 
we are in fact moving ahead without breaking stride, and we are making enormous headway to create pollution abatement programs that will bring us clean air, clean water and a healthy environment. We do not intend to stop. We do not expect because of the energy crisis to abandon our other essential national activities.

It is doubtful that the environmental concerns will be abandoned. However, the pendulum has reached its extremes in respect of the highly publicized environmental matters that once monopolized the front pages. The horror stories have been told, the myths dispelled, the laws have been set into motion and the benefits are yet to be measured.

The time has come for the government and the public to recognize that our survival depends upon a balance being struck between the need for a healthy environment and the necessity of providing adequate energy. It is believed that this balance can be achieved with the aid of an informed public, a far-sighted, accountable government and a responsive industry. 